\title{
A STUDY OF DETERMINANTS OF TRADE IMBALANCE BETWEEN INDIA AND SRI LANKA : 2000-2007
}

\author{
Bo \\ M. RAMANAYAKE \\ MSM/95/38
}

Thesis submitted to the

University of Sri Jayawardenapura for the award of the

Degree of Master of Science in Management 


\section{Declaration Statement}

The work described in this thesis was carried out by me under the supervision of Prof. Upali Wickramasinghe, Professor of Economics, Department of Economics, University of Sri Jayawardenapura and a report on this has not been submitted in whole or in part to any University or any other institution for another Degree / Diploma.

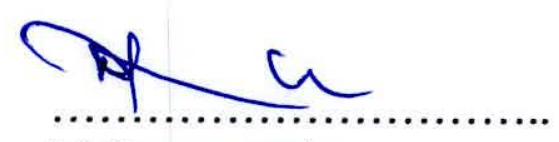

M Ramanayake

(MSM/95/38) 


\section{Supervisor's Declaration Statement}

I certify that the statement made by the candidate is true and that this thesis has been accepted for submission to the University.

$$
\text { Mpuliwsinkw }
$$

Professor Upali Wickramasinghe

(Supervisor)

Professor of Economics

Department of Economics

University of Sri Jayewardenepura

Gangodawila

Nugegoda 


\section{ACKNOWLEDGMENT}

It is with deep sense of gratitude that I acknowledge the immense advice, guidance and encouragement given by my supervisor Prof. Upali Wickramsasinghe, Professor of Economics, Department of Economics, University of Sri Jayawardenapura.

I am deeply indebted to the University of Sri Jayawardenapura and especially the Faculty of Management Studies \& Commerce for providing me the opportunity to follow a Msc Programme which is a worthy experience in life.

I also wish to extend my sincere gratitude to Dr.P.D.Nimal, Course Coordinator, Msc Management Programme, University of Sri Jayawardenapura for all the hardships he had to abide in making the Msc Programme a success. Further to this, I am specially thankful to our Lecturers, Dr. G. Thanthirigama, Dr. (Mrs.) Bhadra Arachchige \& other whose names are not mentioned here, for all the intellectual support delivered to me. My thanks are also due to Ms. Damitha Dissanayake, Ms. Nayomi Devika, Ms. Lakshika Sewwandi for their untiring labour in typing works and Mr. Sanath Hemachandra for his uninstinted support to complete this task.

Finally, I am greatly indebted to my family, especially to my wife and three children who have patiently coped with my tiredness through the course of studies. 


\begin{abstract}
One of the interesting developments in the world economy during the past one and half decade has been the phenomenal growth of regional trading agreements and the significant increase in world trade emerging from these arrangements. Regionalism has become so widespread that at present over 60 per cent of world trade is believed to be taking place among the members of trading blocks.
\end{abstract}

Indo-Lanka Free Trade Agreement (ILFTA) which was fully implemented by March 2008 has resulted in almost fivefold increase in bilateral trade since 2000 to reach US\$ 3.2 billion in 2007 from US\$ 672 million in 2000. The timeframe of tariff phase out between the two countries are now over. The ILFTA implementation period for India was from 2000 to 2003, whereas for Sri Lanka, the implantation period was eight years, from 2000 to 2008.

India has taken a lead over Japan in the post-ILFTA period in terms of its share in Sri Lanka's global imports. In 1999, India's share was 8.5 in Sri Lanka's import and India was the second largest after Japan. But in 2000, India achieved a share of over 16.2 in Sri Lanka's import and became the largest source of imports. Prior to the ILFTA, bilateral trade between India and Sri Lanka grew by just 10 per cent per annum in a seven years period, from 1993-1999. However, ILFTA realty accelerated the trade flow between the two countries and this grew to over 27 per cent in the post-ILFTA period. 
Though there was a significant increase in bilateral trade between India and Sri Lanka after implementation ILFTA, much attention has been focused on the chronic trade imbalance between the two countries as Sri Lanka has been having persistent trade imbalance with India under the bilateral trading environment. This has resulted in the belief that benefits created by bilateral trade between India and Sri Lanka could not be fully realized by the Sri Lankan economy in a balanced manner.

Therefore, an attempt is made in the present study to analyse structure, growth and performance of Indo-Lanka bilateral trade and identify the determinants that led to a growing trade imbalance. The study finds that incerase in import demand for indian goods at a faster rate, insufficient supply capacity of Sri Lanka, lack of trade complementarities between two countries as major factors contributing to the unfavorable trading situation for Sri Lanka. Finally, the study had made recommendations on how to take the two economies forward, towards great integration and sharing the benefits of bilateral trade between the two countries in a more balanced manner. 


\section{TABLE OF CONTENTS}

\section{$\underline{\text { Page No }}$}

Acknowledgement

Abstract

ii-iii

Table of Contents

iv-vi

List of Tables

vii

List of Figures

viii

List of Appendixes

ix

\section{Chapter 01 - Introduction}

1.1 Introduction 1

1.2 Problem Identification 2

1.2.1 Problem Statement 2

1.2.2 Background of the problem 2

1.3 Research Objectives 5

1.4 Significance of the study 5

1.5 Limitation 6

1.6 Chapter Sketch 6

Chapter 2 - Literature Review on bilateral trade agreements

2.1 Introduction 8

2.2 Theories of comparative advantage 8

2.2.1 The Ricadian Theory $\quad 8$

2.2.2 Heckscher - Ohlin Model 11

$\begin{array}{lll}2.3 & \text { Theories of Regional Integration } & 16\end{array}$

2.3.1 The Traditional Theories of Integration 16

2.3.2 Modern Theories relevant to Developing Countries 20

2.4 Literature relating to Regional Cooperation in South Asia 21

$\begin{array}{lll}2.5 & \text { Literature on ILFTA } & 27\end{array}$ 


\section{Chapter 3 - Historical Overview \& Structure of bilateral trade between India \& Sri Lanka}

$\begin{array}{lll}3.1 & \text { Background } & 30\end{array}$

$3.2 \quad$ Bilateral trade after Independence $\quad 32$

3.3 Composition of Indian export 35

3.4 Indo-Lanka Trade Trends between 1993-1998 37

3.5 Composition of Bilateral Trade 39

3.6 Preferential Trading under SAPTA 44

3.7 Indo-Lanka Free Trade Agreement 46

3.7.1 Elimination of tariff by India $\quad 50$

3.7.2 Elimination of tariff by Sri Lanka $\quad 51$

$3.8 \quad$ Trade in service $\quad 52$

3.9 Comprehensive Economic Partnership Agreement (CEPA) 53

3.10 Current Indo-Lanka Trade 55

3.11 Major ILFTA related issues $\quad 63$

3.12 Trade creation and Trade Diversion $\quad 69$

3.12.1 India's preferential import $\quad 69$

3.12.2 Sri Lanka's import from India 70

\section{Chapter 4 - Conceptual Framework and Research Methodology}

$\begin{array}{lll}4.1 & \text { Introduction } & 72\end{array}$

4.2 Development of the Model 72

$\begin{array}{lll}4.3 & \text { Description of the variable used } & 75\end{array}$

$\begin{array}{lll}\text { 4.3.1 Import Demand } & 75\end{array}$

$\begin{array}{ll}\text { 4.3.2 Supply Capacity } & 75\end{array}$

$\begin{array}{lll}4.3 .3 & \text { Trade Complementary } & 76\end{array}$

$\begin{array}{lll}4.4 & \text { Hypotheses Formation } & 77\end{array}$

$\begin{array}{lll}4.5 & \text { Operationalization of variables } & 78\end{array}$

4.5.1 Operationalize of imports Demand 78

4.5.2 Operationalize of supply capacity $\quad 80$

$\begin{array}{ll}\text { 4.5.3 Operationalize of trade complementary } & 81\end{array}$ 
Chapter 5 - Data Presentation \& Analysis

5.1 Introduction 83

5.2 Growth of Import from India 83

5.3 Growth of Export Capacity from Sri Lanka 86

5.3.1 Sri Lanka's Import to Export Ratio $\quad 87$

5.4 Trade Intensity of Indo-Lanka Trade $\quad 89$

5.4.1 Sri Lanka's Import \& Export Intensity with India $\quad 89$

5.5 Reciprocity of Indo-Lanka Trade 91

5.6 Revealed Comparative Advantage (RCA) 93

5.7 Hypothesis Testing 94

5.7.1 Testing Hypothesis $1 \quad 94$

5.7.2 Testing Hypothesis $2 \quad 94$

5.7.3 Testing Hypothesis $3 \quad 95$

Chapter 6 - Discussion of Findings

6.1 Introduction 96

6.2 Research Finding 96

Chapter 7 - Conclusion \& policy Recommendations

$\begin{array}{lll}7.1 & \text { Introduction } & 104\end{array}$

$\begin{array}{lll}7.2 & \text { Recommendation } & 106\end{array}$

$\begin{array}{lll}7.3 & \text { Conclusion } & 112\end{array}$

$\begin{array}{ll}\text { References } & 113\end{array}$

$\begin{array}{ll}\text { Appendixes } & 117\end{array}$ 


\section{LIST OF TABLES}

\section{Chapter 1}

Table 1.1 Bilateral trade between India \& Sri Lanka, 2000-2007

\section{Chapter 3}

Table 3.1 Sri Lanka's Trade with India, 1948-1962

Table 3.2 Trade between Sri Lanka \& India, 1972-1981

Table 3.3 Trade between Sri Lanka and India, 1993-1998

Table 3.4 Growth of Sri Lanka's Import, selected countries, Between 1990 \& 1998

Table 3.5 India's Exports to \& Imports from Sri Lanka and World

Table 3.6 Commodity Composition of India's Trade with Sri Lanka

Table 3.7 Sri Lanka's Trade with SAARC Countries

Table 3.8 Concessions exchanged under ILFTA

Table 3.9 Indian Service Suppliers in Sri Lanka

Table 3.10 Sri Lanka's major imports from India, 2007

Table 3.11 Sri Lanka's major exports to India, 2000

Table 3.12 Top 6 Export items to India, 2005-2006

Table 3.13 Sri Lanka's Exports to India, 2005-2007

\section{Chapter 5}

Table 5.1 Sri Lanka's Trade with India, selected years

Table 5.2 Sri Lanka's imports from India \& world, 1999-2007

Table 5.3 Sri Lanka's Imports from India under FTA concession, selected years

Table 5.4 Sri Lanka's Exports to India \& World, 1998 - 2007

Table 5.5 Imports \& Export Intensity of Sri Lanka with India

Table 5.6 Sri Lanka's Trade Reciprocity with India

Table 5.7 Indo-Lanka Trade Reciprocity

Table 5.8 Revealed Comparative Advantage of Sri Lanka's Top 20 Exports to India 2006 


\section{LIST OF FIGURES}

Figure 1

Figure 2

Figure 3

Figure 4

Figure 5

Figure 6

Figure 7
Growth in Trade Imbalance between India \& Sri Lanka

Indo-Lanka Trade between 1948-1962

Import-Export Growth of Indo-Lanka Trade, 1999-2007

Structure of Sri Lankan export to India, 2005-2007

Conceptual Model on Balance of Trade

Hypothesized Model

Sri Lanka's Import to export Ratio with India 


\section{LIST OF APPENDIXES}

$\begin{array}{ll}\text { APPENDIX I } & \text { - Text of Indo-Lanka Treaty, 1961-74 } \\ \text { APPENDIX II } & \text { - Notice No. 147/2008 of TQB } \\ \text { APPENDIX III } & \text { - List of BOI approved Indian Investment Projects before } 1998 \\ \text { APPENDIX IV } & \text { - Letter of introduction of TRQ on Vanaspathi exports } \\ \text { APPENDIX V } & \text { - List of categories for garments exports to India }\end{array}$




\section{CHAPTER 01}

\subsection{Introduction}

\section{INTRODUCTION}

Trade between India \& Sri Lanka has been taking place for so many years, dating back to several centuries. Sri Lanka is India's largest trading partner in the SAARC region. Today, India has become the largest source of import and the third largest export destination for Sri Lanka, next to USA \& UK according to the annual report of Central Bank for 2007. In particular, bilateral trade and investment links of both countries have deepened and widened considerably over the last eight years. The signing of Indo-Lanka Free Trade Agreement (ILFTA) in December 1998, marked a turning point in economic relations between the two countries according to the detailed data presented in this study. ILFTA is considered to be a shining example of economic cooperation in South Asia by many researchers.

Both countries have exchanged duty free concessions and preferential duty concessions under the South Asian Preferential Trade Agreement (SAPTA) of 1998. SAPTA's slow progress shifted the focus to a bilateral agreement, Indo-Lanka Free Trade Agreement (ILFTA) which came into force in 2000 as a fast track for promoting bilateral trade between the two countries which, has completed eight years of operation. With the initial success of ILFTA and growth in service trade, the scope of the agreement is now being extended to Comprehensive Economic Partnership Agreement (CEPA). Both governments now have finalized negotiations on CEPA which is expected to sustain and build on the momentum generated by ILFTA taking the two economies beyond trade in goods. 
Since independence, Sri Lanka has been having a persistent adverse trade balance with India in bilateral trade. Supply capability of the Sri Lankan economy does not seem to match well with India's demand structure of imports. Sri Lanka's emerging manufacturing structure was "competitive" rather than "complementary" to India's industrial sector and whatever Sri Lanka could produce, India could also produce more cheaply (Kelagama, 1997). Sri Lanka's adverse trade balance with India was US \$ 2229.4 million in 2007 , approximated to $60 \%$ of her adverse trade balance with the entire world, totaling US \$ 3727.4 million (Central Bank Annual Report, 2007). An attempt is made in the present study to analyze the structure and growth of Indo-Sri Lanka bilateral trade and identify the determinants of trade imbalance between the two countries.

\subsection{Problem Identification}

\subsubsection{Problems Statement}

Despite preferential and bilateral trade agreements, which are essentially designed to promote fair competition \& equitable benefits, persistent trade imbalance between India and Sri Lanka does not seem to be narrowing down.

\subsubsection{Background of the problem}

Although the bilateral trade gap in a more integrated world may not be such a useful measure to point out the health of the economy under the multilateral trading environment, it is important, however, to identify the determinants of trade imbalance of the two countries under the bilateral trade agreement with the exchange of 
preferential and duty free concessions as benefits of bilateral trade are to be shared by both countries.

Bilateral trade between India \& Sri Lanka has grown rapidly in recent years. India is now the largest trading partner in South Asia and the largest supplier of imports to Sri Lanka, ahead of Japan in 1995, followed by Singapore, Hong Kong. India has become the third largest export destination of Sri Lanka. Table 1.1 presents the bilateral trade figures between India \& Sri Lanka from 2000 to 2007.

\section{Table 1.1}

\section{Bilateral Trade between India and Sri Lanka, 2000-2007}

\begin{tabular}{|c|c|c|c|c|}
\hline Year & $\begin{array}{c}\text { Imports from } \\
\text { India }\end{array}$ & $\begin{array}{c}\text { Exports to } \\
\text { India }\end{array}$ & $\begin{array}{c}\text { Sri Lanka's trade } \\
\text { balance }\end{array}$ & $\begin{array}{c}\text { EXIM Ratio } \\
\text { SL imports/SL } \\
\text { Exports }\end{array}$ \\
\hline 2000 & 600.1 & 55.7 & -544.5 & $10.3: 1$ \\
\hline 2001 & 601.5 & 70.1 & -531.4 & $8.4: 1$ \\
\hline 2002 & 834.6 & 168.7 & -665.9 & $4.9: 1$ \\
\hline 2003 & 1076.2 & 241.1 & -835.0 & $4.4: 1$ \\
\hline 2004 & 1358.0 & 385.5 & -972.5 & $3.5: 1$ \\
\hline 2005 & 1439.5 & 589.1 & -880.5 & $2.5: 1$ \\
\hline 2006 & 1805.2 & 486.5 & -1315.7 & $3.6: 1$ \\
\hline 2007 & 2744.3 & 514.9 & -2229.4 & $5.3: 1$ \\
\hline
\end{tabular}

\section{Source: Central Bank of Sri Lanka, Annual Report - 2008}

While bilateral economic ties between India \& Sri Lanka are robust, they have been characterized from its inception by a growing bilateral trade imbalance. Initially, the balance in India's favor was small but after signing of Indo - Sri Lanka trade agreement in 1998, it has grown substantially and now constitutes the largest single bilateral trade deficit of Sri Lanka. 